\title{
Noninvasive alternatives for DNA collection from threatened rodents
}

\author{
Michelle L. Green ${ }^{1,2}$, Tih-Fen Ting ${ }^{3}$, Mary Beth Manjerovic ${ }^{1,2}$, Nohra Mateus-Pinilla ${ }^{1^{*}}$, \\ Jan Novakofski ${ }^{1}$ \\ ${ }^{1}$ Illinois Natural History Survey, University of Illinois Urbana-Champaign, Champaign, USA; \\ *Corresponding Author: nohram@,illinois.edu \\ ${ }^{2}$ Department of Animal Sciences, University of Illinois Urbana-Champaign, Urbana, USA \\ ${ }^{3}$ Department of Environmental Studies, University of Illinois Springfield, Springfield, USA
}

Received 15 March 2013; revised 16 April 2013; accepted 2 May 2013

Copyright (C) 2013 Michelle L. Green et al. This is an open access article distributed under the Creative Commons Attribution License, which permits unrestricted use, distribution, and reproduction in any medium, provided the original work is properly cited.

\begin{abstract}
Many rodent species are currently under conservation threat. However, population monitoring and status assessment are extremely challenging because of small body size, low abundance and elusive behavior of rodents. Furthermore, invasive methods of capture and tissue collection commonly used to address such studies can induce an unacceptable amount of stress to sensitive species. As a result, noninvasive techniques have become more widely used, but relatively few studies have applied noninvasive techniques to rodents. Here we present two noninvasive alternatives for the collection of DNA from Franklin's ground squirrels (Poliocitellus franklinii). We compared the quantity, purity and degradation of DNA extracted from plucked hair and fecal pellets to tail snip tissues. We recovered more DNA from tail snips than either plucked hair or fecal pellets. Both hair and fecal pellets recovered DNA with purity ratios similar to tail snips. As expected, DNA recovered from fecal pellets exhibited a high degree of degradation compared to hair and tail tissues. Careful planning of field and laboratory protocols is therefore necessary to compensate for challenges associated with noninvasive tissue types. While there is no tissue that can universally be applied to all research projects, both hair and feces are viable alternatives to traditional invasive procedures and can be applied to threatened and endangered rodent species.
\end{abstract}

Keywords: Noninvasive; Hair; Fecal; Rodent; Threatened

\section{INTRODUCTION}

With the ever encroaching human wildlife interface and continued loss of biodiversity, the need for conservation solutions and management is growing. Threatened and endangered rodents often are better known as pests resulting in the oversight of critical conservation issues. The order Rodentia constitutes a major component of mammalian biodiversity representing over $40 \%$ of all known mammal species. Approximately one quarter of those rodent species are listed at the federal level [1] suggesting a need for better management methods.

Several factors make population monitoring and species status assessment of rodents challenging [2]. Direct observation of rodents is challenging and live trapping may be expensive, work intensive [3], and disruptive to some species [4]. In addition, low abundance and elusive behavior results in low trap success but noninvasive genetic methods can provide population information without trapping or handling. Genetic sampling has become more commonly used to identify the presence of rodent species [5] and provides information on the population characteristics of rare species [6,7]. Tissue samples obtained from noninvasive methods have provided DNA suitable for population monitoring, mark-recapture abundance estimation, relatedness, genetic population structure and phylogenetics [8-14].

Skeletal muscle tissue collection via tail snip [15], ear punch [16] and toe clip [17] are common sources of DNA when working with rodents. However, when studying sensitive populations, noninvasive methods are preferred. Noninvasive techniques allow for genetic sample collection but circumvent the need for animal handling, which is often difficult or impossible when monitoring threatened and endangered species. Common noninvasive sources of DNA are hair and feces because 
both nuclear (nDNA) and mitochondrial DNA (mtDNA) can be amplified from single shed hairs, plucked hair [18] and feces [5]. Hair samples have been used previously to collect DNA from several small rodent species including the wood mouse (Apodemus sylvaticus), bank vole (Myodes glareolus), common shrew (Sorex araneus), pygmy shrew (Sorex minutus) and Eurasian water shrew (Neomys fodiens) [5]. Hair is generally considered a noninvasive option; however hair may be collected either with or without trapping and handling. Fecal samples are considered completely noninvasive because collection of feces does not require the animal to come in contact with a collection device. Fecal studies are becoming more widespread with studies completed in birds [19], felids [20, 21], canines [22], bears [23], primates [24], and aquatic mammals [25-29]. However, relatively few studies have assessed the use of fecal pellets as a source of DNA in small mammal species. Fecal mtDNA was successfully used to identify vole species in Europe [3] and both mtDNA and nDNA were used to identify rodent species in Iberia [30] and the UK [5]. Although informative, generating reliable data from noninvasive samples is challenging because of the low quantity and quality of recovered DNA [31]. As a result, developing optimal field and laboratory protocols are crucial to the success of noninvasive studies.

As the only species in the genus Poliocitellus, the range of Franklin's ground squirrel (Poliocitellus franklinii) extends from the central United States to the southern Canadian plains (Figure 1) [32-35]. Franklin's ground squirrels are declining in much of the central United States because of habitat loss and fragmentation. Its distribution is limited by isolation of suitable grassland habitat, specifically, the presence of tall, dense vegetation

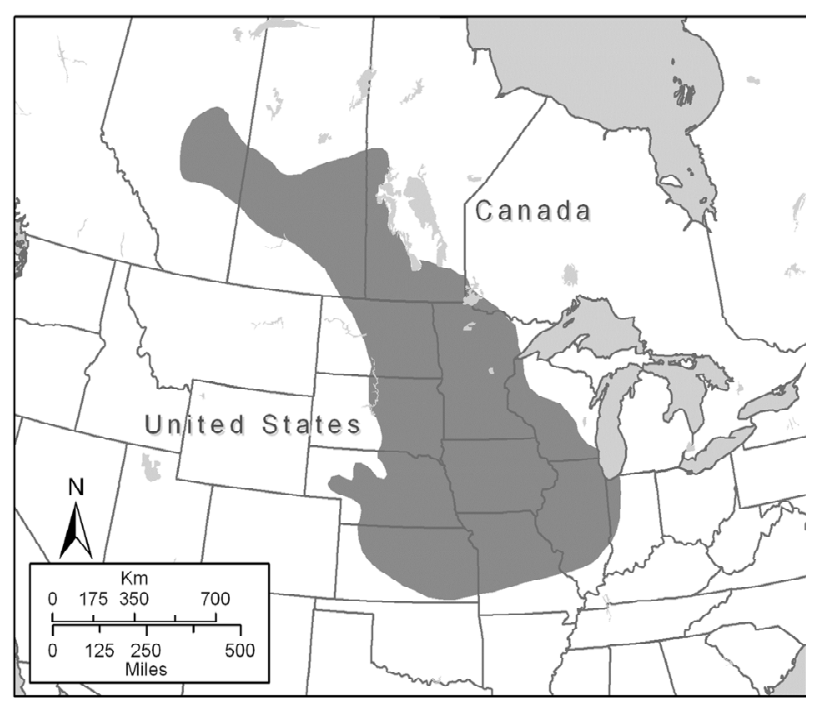

Figure 1. Map of Franklin's ground squirrel (Poliocitellus franklinii) range (from Helgen et al. [32]). typically lacking in landscapes dominated by agriculture. Franklin's ground squirrels are threatened in Illinois [36], endangered in Indiana [37], vulnerable in Iowa [38], imperiled and vulnerable in Missouri [39], and vulnerable in Wisconsin [40]. In Illinois recent effort has been made to improve the habitat and understand local connectivity of the species. Franklin's ground squirrels are considered the least social of all the ground squirrel species [34-35] and its highly secretive nature makes detection and abundance estimation particularly difficult.

In addition to secretive behavior, Franklin's ground squirrels typically hibernate from August through April further limiting observation opportunities. Males emerge from hibernation one to two weeks before females to establish dominance hierarchies. Juveniles disperse at 9 11 weeks of age, with males usually dispersing farther than females. Continued habitat loss and fragmentation can prevent successful dispersal and gene flow between populations, leading to a loss of genetic variability for Franklin's ground squirrels.

The objective of this study was to determine if there are measurable differences in the quantity and quality of DNA recovered from tissues of Franklin's ground squirrels using noninvasive sampling techniques compared to traditional invasive methods. As such, we compared the total yield, purity and degradation of genomic DNA extracted from plucked hair, fecal pellets and tail snips.

\section{MATERIALS AND METHODS}

\subsection{Study Site and Sample Collection}

We obtained samples from Franklin's ground squirrels trapped as part of a concurrent study in Sangamon County, Illinois. Several colonies of Franklin's ground squirrels occur along sections of an abandoned railroad corridor that extends north-south $(61 \mathrm{~km})$ through the western part of the county. We live trapped (Model 202, Tomahawk Live Trap, Hazelhurst, WI) along the corridor from late May to early August 2012 and individually tagged animals with passive integrated transponders (Biomark HPT 9, Boise, ID). Traps were set at 0700, closed by 1500 and traps were shut during rain. Because ground squirrels are susceptible to heat shock, we checked traps in two hour intervals, covered traps with dense vegetation to provide sun and heat protection, and reduced the handling time.

Using forceps, more than ten hairs were pulled from the tip of the tail and stored in air-tight containers with a desiccant. Fecal samples were collected opportunistically during each trap event. Because DNA quality is affected by fecal sample age [30,41], we ensured collection of fresh fecal samples by only using feces collected in the mesh handling bag rather than the trap. We collected all intact pellets with forceps and transferred whole pellets 
directly to $95 \%$ ethanol for storage; broken pellets were avoided and care was taken to avoid crushing the pellets during collection and transfer [42]. Tail snips were collected during the first trap event for each individual. A small $(\sim 2 \mathrm{~mm})$ piece of tissue was removed from the tip of the tail using sterile scissors. A commercial clotting agent (Kwik Stop styptic powder; Gimborn US Inc., Atlanta, GA) was applied to the wound to reduce bleeding. Tail tissue samples were transferred directly to $95 \%$ ethanol for transportation and storage. All handling and tissue collection were in accordance with the American Mammal Association guidelines [43] and were approved by the University of Illinois Springfield Institutional Committee for the Care and Use of Animals (\#035).

\subsection{DNA Extraction}

We extracted genomic DNA from all tissue types using the DNeasy Tissue Kit (Qiagen Inc., Valencia, CA) according to the manufacturer's protocol. To maximize DNA yield from each sample, two elutions (A and B) were collected in all extractions. The elution (buffer AE, Qiagen) consisted of $10 \mathrm{mM}$ Tris- $\mathrm{HCl}$ and $0.5 \mathrm{mM}$ EDTA.

Tail tissue - Genomic DNA was extracted from tail tissues with the following modifications. Each sample was digested for at least 24 hours in $360 \mu \mathrm{L}$ of buffer ATL and $60 \mu \mathrm{L}$ proteinase $\mathrm{K}(>600 \mathrm{mAU} / \mathrm{ml}$, Qiagen). The lysate was centrifuged for $5 \mathrm{~min}$ at $20,000 \times \mathrm{g}$ after digestion. The supernatant was transferred to a new tube used for subsequent extraction steps. To adjust for the increased volume of ATL and proteinase K, $400 \mu \mathrm{L}$ buffer AL and $400 \mu \mathrm{L}$ ethanol were used to ensure binding of DNA to the filter membrane. Elution volumes were $200 \mu \mathrm{L}$.

Hair-Hair samples were visually inspected. Hairs with roots were selected for DNA extraction. Excess hair shaft was removed from ten hairs, leaving $\sim 1 \mathrm{~cm}$ piece of hair bulb and shaft. Samples were gently agitated $(\sim 180$ rpm) on an orbital shaker while digesting overnight at $56^{\circ} \mathrm{C}$ in a solution of dithiothreitol, proteinase $\mathrm{K}$, and buffer ATL (Qiagen). Upon complete digestion, samples were vortexed and the extraction protocol completed following manufacturer guidelines. Elution volumes were $200 \mu \mathrm{L}$.

Feces-Fecal DNA was extracted using the fecal pellet modifications described by Brinkman et al. [44] and Maudet et al. [42]. Pellets were transferred from storage tubes to $25 \mathrm{~mL}$ glass scintillation vials using sterile forceps. We varied the number of pellets ( $1-3$ and $>3)$ used in extraction runs to determine if there was variation in DNA yield. Crushing of pellets during transfer was carefully avoided. The outer mucous layer containing sloughed intestinal cells was washed from the pellets using 800 $\mu \mathrm{L}$ of buffer ATL (Qiagen). Samples were gently agitated $(\sim 180 \mathrm{rpm})$ on an orbital shaker for one hour at room temperature. Following washing, $400 \mu \mathrm{L}$ of the wash solution was transferred to $1.5 \mathrm{~mL}$ microcentrifuge tubes and the standard extraction protocol completed. To concentrate DNA yield, two $50 \mu \mathrm{L}$ elutions were carried out.

\subsection{Estimation of DNA Yield, Purity and Degradation}

The total DNA yield and purity of each elution were estimated using a Nanodrop ${ }^{\mathbb{B}} 2000$ (Nanodrop Technologies, Wilmington, DE). The nucleic acid content (ng/ $\mu \mathrm{L})$ of each sample was measured in triplicate using $2.0 \mu \mathrm{L}$ undiluted aliquots. Each aliquot concentration was multiplied by the total elution volume to determine the total DNA yield and mean values calculated. The purity of extracted DNA was estimated by measuring the A260/ A280 absorbance ratio in triplicate. Pure nucleic acid solutions have ratios of approximately 1.8 .

DNA degradation was evaluated by electrophoresis on agarose gels. All samples $(5.0 \mu \mathrm{L})$ were mixed with $1 \mu \mathrm{L}$ of 5X DNA blue loading buffer (Bioline USA Inc., Taunton, MA) and run against a standard ladder (Hyperladder IV, Bioline USA Inc.). Each sample was electrophoresed $(50$ minutes, $120 \mathrm{~V})$ on $2 \%$ agarose gels pre-stained with ethidium bromide to assess the general quantity and fragmentation of DNA. The intensity of each sample was compared to the standard and the amount of small fragment DNA noted.

Statistical analyses were carried out in SAS v. 9.2 (SAS, Cary, NC). Where possible, data were log transformed to fit normal distribution curves. Nonparametric analyses were used for datasets that did not fit normal distribution curves following transformation. We tested for differences in DNA yield and purity using a general linear model (Proc GLM) or Kruskal-Wallis and Wilcoxon rank tests (Proc NPAR1WAY). Initial model predictors included tissue type, elution, and sex. Sexual dimorphism in species may result in smaller gastrointestinal tracts in one sex, potentially producing smaller pellet sizes. Reduced mucosal surface area of small pellets may decrease DNA yield and therefore, sex was included as a predictor in the model. Only predictors showing an association at a significance of 0.05 were included in the final models and considered significant. For comparisons of significant differences, Tukey's "honest significant difference" post-hoc method was applied.

\section{RESULTS}

Tail tissue, hair and fecal samples were collected from eleven individual Franklin's ground squirrels (7 female, 4 male). We found a difference in the $\log$ DNA yield between elutions $(\mathrm{F}=40.86, P<0.0001)$. Elution $\mathrm{A}$, consistently recovered a larger amount of DNA (Table 1). Based on this difference, we reanalyzed the data in two elution groups with tissue type and sex defined as inde- 
pendent variables. Sex was not a significant predictor of DNA yield in either elution group. The amount of DNA recovered from each tissue type was different in elution A only $(\mathrm{F}=5.87, P=0.007)$. In elution $\mathrm{A}$, the $\log \mathrm{DNA}$ yield recovered from tail tissue was significantly greater than both hair and fecal samples (Tukey's post hoc test $\alpha$ $=0.05$ ).

Absorbance ratios of elution $\mathrm{A}$ and $\mathrm{B}$ were different (Wilcoxon signed rank test: $P=0.004$ ). Elution A solutions generated absorbance ratios closest to the ideal ratio of $1.8(\mathrm{M}=1.72, \mathrm{SE}=0.08)$ but the average ratio among elution $\mathrm{B}$ solutions was greater $(\mathrm{M}=1.94, \mathrm{SE}=0.07)$. There was no difference in the quality of DNA recovered based on sex. When all samples, regardless of elution were combined, there was a difference in the quality ratios based on tissue type (Kruskal-Wallis: $P=0.005$ ). However, when analyzed separately, differences in tissue type were only found among elution A samples (KruskalWallis: $P=0.002$ ). Among elution A samples, tail and fecal tissues exhibited similar absorbance ratios (Table 1, Wilcoxon signed rank test: $P=0.65)$. Hair DNA ratios were low in elution $\mathrm{A}(\mathrm{M}=1.39, \mathrm{SE}=0.69)$ and differed significantly from tail and fecal ratios (Wilcoxon signed rank test: hair v. tail $P=0.001$; hair v. feces $P=0.006$ ). Elution $\mathrm{B}$ hair ratios were closer to pure DNA $(\mathrm{M}=1.88$, $\mathrm{SE}=0.08)$. In both elution $\mathrm{A}$ and $\mathrm{B}$, fecal samples were closest to the target of 1.8 (Table 1). Elution B recovered more pure samples than elution $\mathrm{A}$ in the noninvasive tissues.

Visual comparisons of extracted DNA on agarose gels revealed quantity outcomes similar to Nanodrop ${ }^{\circledR}$ results. A greater amount of small fragment DNA was observed in fecal samples compared to both tail tissue and hair, although all samples, regardless of tissue type recovered large fragments of DNA (Figure 2).

To test for variation in DNA yield based on the number of fecal pellets used, samples were collected from 27 individuals and 32 extractions completed. One to seven pellets were used in each extraction $(\mathrm{M}=2.30, \mathrm{SE}=$ 0.22 ). We did not identify a substantial increase in DNA yield by increasing the number of pellets used in the extraction protocol (Figure 3, Wilcoxon signed rank test: Elution A: $P=0.39$, Elution B: $P=0.26$ ).

\section{DISCUSSION}

Noninvasive methodologies provide usable DNA for use in conservation of threatened and endangered species, enabling genetic studies that cannot be completed with tissue samples. In Franklin's ground squirrels, we found both hair and feces provided similar amounts of DNA although tail tissue provided the greatest amount of DNA compared to both noninvasive sources. In our study, we collected a fraction $(\sim 2 \mathrm{~mm})$ of the length of tail recommended by the commercial kit and thus DNA yield was lower than kit expectations. However, even with a reduction of starting material, we recovered adequate amounts of DNA for downstream applications. Plucked hairs recovered less DNA but the number of hairs used in our extractions may have restricted our yield. In our protocol, we tested a set number of hair bulbs $(n=10)$. Increasing the number of hairs in the initial digestion may increase the quantity of DNA recovered [45]. Increasing the number of fecal pellets in each extraction does not appear to increase DNA yield. Fecal pellets recovered the smallest amount of DNA, although there was a great deal of variation in DNA yield. The fact that DNA yield cannot be improved by simply increasing the number of pellets may be a result of the order in which pellets are released from the digestive tract. Pellets that are excreted first may collect a higher proportion of sloughed cells but because pellet excretion order cannot be determined during field collection, pellet selection will not enhance DNA yield. Furthermore, overloading vials with multiple pellets may reduce the effectiveness of the wash procedure and ultimately reduce DNA recovery. Therefore, if more pellets are used, it is best to divide pellets among multiple scintillation vials to ensure cells are washed from the pellet surface.

Table 1. Total amount of DNA and purity ratios recovered from three different tissue types collected from Franklin's ground squirrels (Poliocitellus franklinii). Two sequential elutions (A and B) per extraction are reported. The given numbers for DNA yield (Yield $\mu \mathrm{g}$ ) and purity ratios (Ratio) are rounded mean values of triplicate measurements with the NanoDrop ${ }^{\circledR}$ spectrophotometer and rounded values for the standard error (SE).

\begin{tabular}{cccccccccccccccc}
\hline \multicolumn{10}{c}{ Elution A } \\
\hline Type & $\mathrm{N}$ & Yield $(\mu \mathrm{g})$ & $\mathrm{SE}$ & Range & Ratio & SE & Range & Yield $(\mu \mathrm{g})$ & SE & Range & Ratio & SE & Range \\
Tail & 11 & 6.09 & 1.09 & $0.76-14.61$ & 1.93 & 0.03 & $1.85-2.15$ & 1.30 & 0.27 & $0.44-2.99$ & 2.20 & 0.09 & $1.75-2.80$ \\
Hair & 11 & 2.89 & 0.57 & $0.78-6.97$ & 1.39 & 0.21 & $0.00-2.13$ & 1.20 & 0.13 & $0.56-1.86$ & 1.88 & 0.08 & $1.57-2.38$ \\
Fecal & 11 & 2.15 & 0.39 & $0.64-4.77$ & 1.84 & 0.06 & $1.41-2.06$ & 0.87 & 0.26 & $0.07-2.75$ & 1.79 & 0.15 & $0.60-2.15$ \\
\hline
\end{tabular}




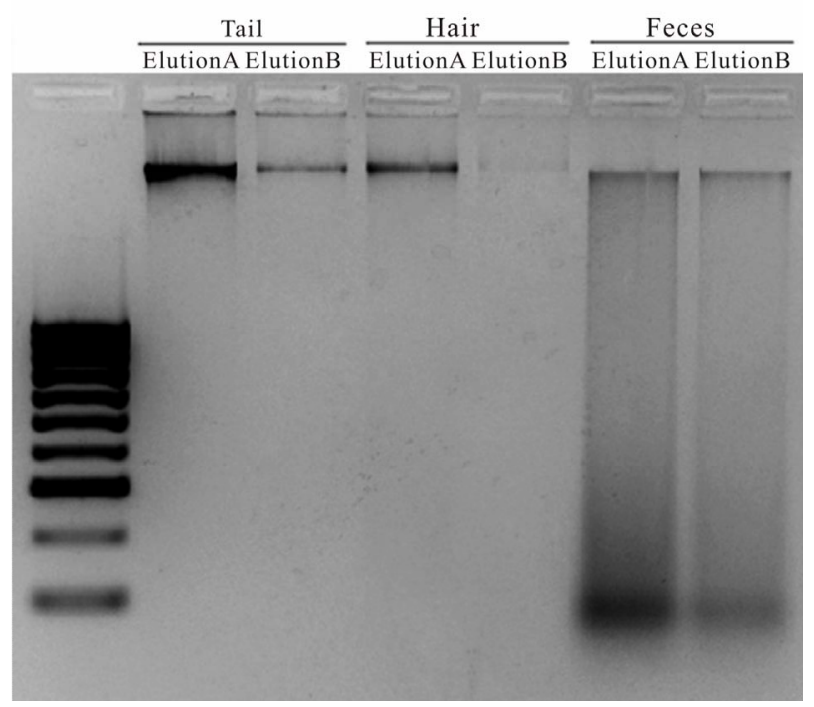

Figure 2. Representative examples of DNA recovered from Franklin's ground squirrel (Poliocitellus franklinii) tissues. DNA $(5 \mu \mathrm{L})$ was mixed with $5 \mathrm{X}$ DNA blue loading buffer and run against a $100 \mathrm{bp}$ standard ladder (Bioline USA Inc.). The ladder included fragment sizes ranging from $100 \mathrm{bp}(0.04 \mu \mathrm{g})$ to $1013 \mathrm{bp}(0.10 \mu \mathrm{g})$. All three tissues recovered large fragment DNA ( $>1013 \mathrm{bp})$. DNA recovered from fecal pellets contained a relatively large amount of small, fragment DNA $(\sim 100 \mathrm{bp})$ that was not observed in either tail or hair DNA.
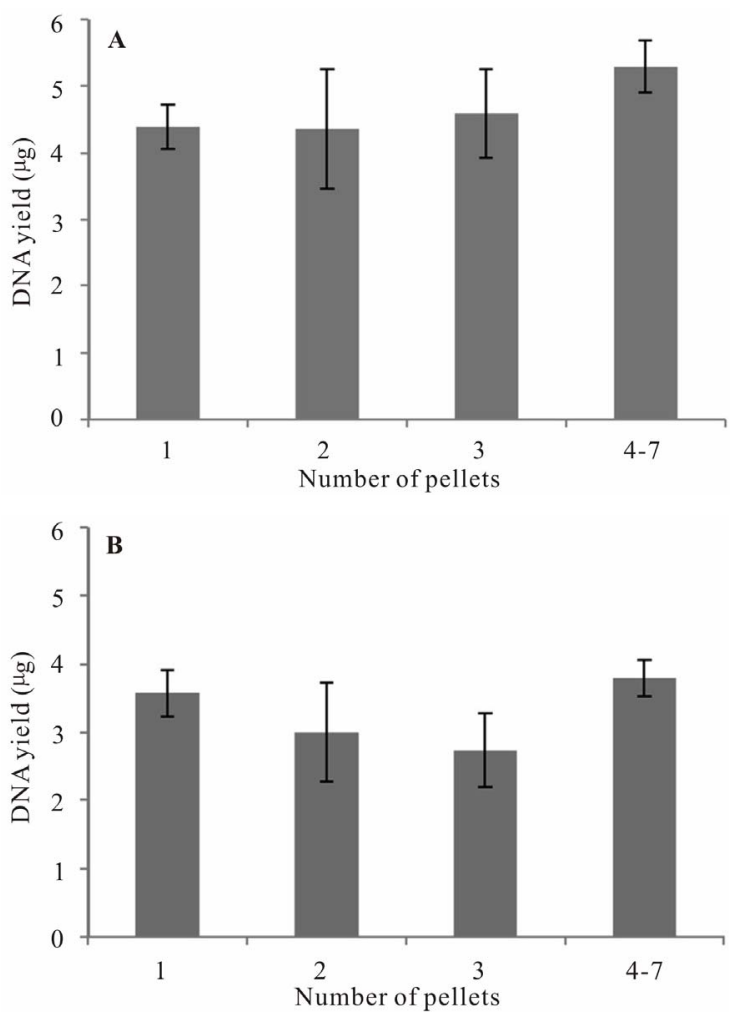

Figure 3. Mean DNA yield $(\mu \mathrm{g})$ recovered from Franklin's ground squirrel (Poliocitellus franklinii) fecal pellets. Panel A represents extraction elution A; Panel B represents extraction elution B.
The DNA recovered from tail tissues was good quality and devoid of fragmentation. Although DNA recovery from hair was lower, there was no fragmentation observed in the samples. Fecal DNA was more degraded than hair or tail tissues. Degradation is a common feature of fecal DNA and likely occurs as a result of oxidative, hydrolytic and enzymatic damage [46]. In our study, hair and fecal DNA recovered in elution B was higher quality than DNA recovered in the first elution. Tail tissue purity was not improved in elution $\mathrm{B}$; rather elution $\mathrm{A}$ was closer to the expected DNA absorbance ratio. Therefore, depending on the tissue selected, downstream applications may be improved by selecting the higher quality elution.

Low quantity and quality of DNA recovered from noninvasive sources results in increased genotyping error rates over traditional tissue samples. Genotyping error can occur because of preferential amplification of one allele (i.e., allelic drop-out) or false alleles and is problematic because it can result in errantly typing individuals as homozygous when they are in fact heterozygous [47]. To accurately interpret genetic data, error rate calculations must be completed when genotyping from noninvasive tissues [48]. Repeating amplification reactions [47], comparing initial amplification attempts to consensus genotypes [49] and blind repeat tests provide genotyping error rates. Error rates are variable depending on the tissue, DNA yield and quality, and amplification procedures. Using hair from spotted-tail quolls (Dasyurus maculatus), error rates ranged from $1.5 \%-6.5 \%$, although error rates were reduced by pooling extracts using multiple hairs [50]. Gagneux et al. [51] found an overall genotyping error rate of $37 \%$ among shed chimpanzee (Pan troglodytes verus) hairs but reduced error rate to $<0.01 \%$ using plucked hairs. Using one to four hair bulbs, genotype failure occurred among $37.3 \%$ of grizzly bear samples (Ursus arctos) [52] and 8\% of black bear (Ursus americanus) and grizzly bear samples [53]. Goossens et al. [45] examined the relationship between genetic identification failure and the number of roots in a sample and found failure rate declined as the number of roots in the sample increased. Fecal error rates are also variable. Genotyping failure of $48 \%$ was reported among mouflon (Ovis musimon) fecal samples [42] but was as high as $88 \%$ among Sitka black-tailed deer (Odocoileus hemionus sitkensis) [54]. Fecal error rates can be greatly reduced by using a modified multiple tubes approach and fresh samples as was seen among Atlantic spotted dolphin (Stenella frontalis) fecal samples (genotyping error range $0.0 \%-1.7 \%$ ) [48].

Although noninvasive samples have limitations, those restrictions can be overcome using specific protocols. When planning a noninvasive study, both the single tube and multiple tube approaches should be considered. The 
single tube approach requires more DNA to generate reliable PCR products and generally requires a single amplification. This is the standard approach when using high yield tissues such as blood and skeletal muscle. The multiple tube approach divides the sample among several tubes and the contents of each tube are amplified separately. This approach is designed to work with extremely low quantity DNA samples but requires multiple PCR reactions at each locus to determine a consensus genotype $[55,56]$. The obvious drawback of the multiple tubes approach is the extra expense of conducting several amplifications per locus per sample. The single tube approach will require less laboratory effort and cost to generate genotypes but field and sampling conditions may restrict the tissue collection and therefore the amount of recovered DNA.

To increase the likelihood of amplification success, downstream applications should target smaller fragments. DNA was clearly degraded in fecal samples and in keratinized cells of telogen hair. Nuclear DNA from keratinized hair cells was generally 100 bp in size [57] and short amplicon targets increase genotyping success rate [58]. Because fecal DNA was also degraded, short target fragments should increase genotyping success. Fragments sizes up to $213 \mathrm{bp}$ have been successfully amplified from fecal samples collected in an aquatic environment $[26,48]$.

In addition to laboratory logistics, researchers need to consider the necessary field logistics to carry out sample collection. The amount of animal handling to be completed in the field may determine the appropriate tissue type. If handling is required to gather additional morphometric data (e.g., body weight), all three tested tissues are options. Tail tissue will provide greater amounts of DNA that is devoid of degradation and fragmentation but it requires the most invasive handling. Specific care should be taken when collecting tail tissue samples in extreme temperatures. In extreme heat, vasodilation directs blood to the surface of the tail for rapid heat exchange and may result in excessive bleeding when collecting tail snips. Commercially available clotting agents or topical freeze sprays can be applied to reduce bleeding. However, when working with sensitive species, the additional stress placed on the animal during tail snip procedures may not be acceptable.

If handling will occur, but tail snip stress is unacceptable, hair plucking is a reasonable alternative. An alternative to trapping and handling animals for hair collection is the use of hair traps, tubes and snares [59-61]. These methods often recover shed telogen hairs that lack roots. While shed hairs can be used for genetic analyses, there is as estimated 95\% reduction in recovered DNA compared to plucked hairs $[18,51]$. If hair traps are designed using strong adhesives, the number of plucked hairs increases, however, special care must be taken to remove both the hair shaft and bulb from the adhesive before advancing to extraction [62]. Even when hair bulbs are recovered, genotyping success may still be low. If possible, we recommend multiple collections from individuals and the multiple tubes approach to increase genotype accuracy.

Fecal samples provide an avenue to collect DNA without requiring the animal to interact with a collection device. However, the frequency of collection requires consideration because environmental exposure of the feces should be minimized. Seasonal variation often impacts genotyping success when using feces. Rainfall and warm ambient temperatures tend to increase DNA degradation. Genotyping success of Sitka black-tailed deer increased from $22 \%$ to $80 \%$ when the fecal pellets were protected from rainfall [54]. Depending on environmental factors such as temperature and rainfall, one season may provide better genotyping success. Maudet et al. [42] found genotyping error increased when fecal samples were collected in the spring ( $52 \%$ - 59\% genotype success) compared to winter collection (95\% - 99\% genotype success). In addition, regardless of season, increased time of environmental exposure prior to DNA extraction will decrease genotyping success. In fact, no deer samples were successfully genotyped after fecal pellets were exposed for more than seven days [42].

Given the variation in both quantity and quality of recovered DNA, use of noninvasive tissues in downstream applications will require optimization. Both hair and fecal samples are useful alternatives to invasive tail snips, however, careful planning of the field and laboratory protocols is necessary to compensate for the challenges associated with small quantities of DNA. There is no tissue that can universally be applied to all research projects; however noninvasive methods are a viable alternative to traditional invasive procedures and can be applied to threatened and endangered rodent species.

\section{ACKNOWLEDGEMENTS}

This project was supported by the Illinois Department of Natural Resources through the Federal Aid in Wildlife Restoration Program (Project W-170-R), the University of Illinois Springfield and the University of Illinois Urbana-Champaign Office of the Vice Chancellor for Research. The authors thank the field and laboratory technicians that assisted with this project as well as W. Brown for constructing the distribution map.

\section{REFERENCES}

[1] IUCN (2012) IUCN red list of threatened species. Version 2012.2.

[2] Álvarez-Castañeda, S.T. and Ortega-Rubio, A. (2003) Current status of rodents on islands in the Gulf of Cali- 
fornia. Biological Conservation, 109, 157-163. doi:10.1016/S0006-3207(02)00121-0

[3] Alasaad, S., Soriguer, R.C., Jowers, M.J., Marchal, J.A., Romero, I. and Sánchez, A. (2011) Applicability of mitochondrial DNA for the identification of Arvicolid species from faecal samples: A case study from the threatened Cabrera's vole. Molecular Ecology Resources, 11, 409414. doi:10.1111/j.1755-0998.2010.02939.x

[4] Moncrief, N.D., Van Den Bussche, R.A., Dueser, R.D., Loftis, D., Cockett, N.E. and Culver, M. (2008) Diagnostic genetic marker than differentiates Eastern fox squirrels from Eastern gray squirrels. The Journal of Wildlife Management, 72, 320-323. doi:10.2193/2006-149

[5] Moran, S., Turner, P.D. and O'Reilly, C. (2008) Noninvasive genetic identification of small mammal species using real-time polymerase chain reaction. Molecular Ecology Resources, 8, 1267-1269. doi:10.1111/j.1755-0998.2008.02324.x

[6] Kohn, M. and Wayne, R.K. (1997) Facts from feces revisited. Trends in Ecology and Evolution, 12, 223-227. doi:10.1016/S0169-5347(97)01050-1

[7] Piggott, M.P. and Taylor, A.C. (2003) Remote collection of animal DNA and its applications in conservation management and understanding the population biology of rare and cryptic species. Wildlife Research, 30, 1-13. doi:10.1071/WR02077

[8] Eggert, L.S., Eggert, J.A. and Woodruff, D.S. (2003) Estimating population sizes for elusive animals: The forest elephants of Kakum National Park, Ghana. Molecular Ecology, 12, 1389-1402. doi:10.1046/j.1365-294X.2003.01822.x

[9] Fernando, P., Pfrender, M.E., Encalada, S.E. and Lande, R. (2000) Mitochondrial DNA variation, phylogeography and population structure of the Asian elephant. Heredity, 84, 362-372. doi:10.1046/j.1365-2540.2000.00674.x

[10] Garnier, J.N., Bruford, M.W. and Goossens, B. (2001) Mating system and reproductive skew in the black rhinoceros. Molecular Ecology, 10, 2031-2041. doi:10.1046/j.0962-1083.2001.01338.x

[11] Höss, M., Kohn, M., Pääbo, S., Knauer, F. and Schröder, W. (1992) Excrement analysis by PCR. Nature, 359, 199. doi:10.1038/359199a0

[12] Kohn, M., Knauer, F., Stoffella, A., Schröder, W. and Pääbo, S. (1995) Conservation genetics of the European brown bear-A study using excremental PCR of nuclear and mitochondrial sequences. Molecular Ecology, 4, 95103. doi:10.1111/j.1365-294X.1995.tb00196.X

[13] Lucchini, V., Fabbri, E., Marucco, F., Ricci, S., Boitani, L. and Randi, E. (2002) Noninvasive molecular tracking of colonizing wolf (Canis lupus) packs in the western Italian Alps. Molecular Ecology, 11, 857-868. doi:10.1046/j.1365-294X.2002.01489.x

[14] Kohn, M.H., York, E.C., Kamradt, D.A., Haught, G., Sauvajot, R.M. and Wayne, R.K. (1999) Estimating population size by genotyping faeces. Proceedings of the Royal Society B, 266, 657-663. doi:10.1098/rspb.1999.0686

[15] Spriggs, D.R. (1987) Transgenic mice and the language of cells. The Journal of Infectious Diseases, 155, 596-597.

\section{doi:10.1093/infdis/155.3.596}

[16] Wang, R., Painter, J.N. and Hanski, I. (2002) Amplification of DNA markers from scat samples of the least weasel Mustela nivalis nivalis. Acta Theriologica, 47, 425431. doi:10.1007/BF03192467

[17] Aars, J., Ims, R.A., Liu, H.-P., Mulvey, M. and Smith, M.H. (1998) Bank voles in linear habitats show restricted gene flow as revealed by mitochondrial DNA (mtDNA). Molecular Ecology, 7, 1383-1389. doi:10.1046/j.1365-294x.1998.00487.x

[18] Higuchi, R., von Beroldingen, C.H., Sensabaugh, G.F. and Erlich, H.A. (1988) DNA typing from single hairs. Nature, 332, 543-546. doi:10.1038/332543a0

[19] Broderick, D., Idaghdour, Y., Korrida, A. and Hellmich, J. (2003) Gene flow in great bustard populations across the Strait of Gibraltar as elucidated from excremental PCR and mtDNA sequencing. Conservation Genetics, 4, 793800. doi:10.1023/B:COGE.0000006111.65204.c9

[20] Ernest, H.B., Penedo, M.C.T., May, B.P., Syvanen, M. and Boyce, W.M. (2000) Molecular tracking of mountain lions in the Yosemite Valley region in California: Genetic analysis using microsatellites and faecal DNA. Molecular Ecology, 9, 433-441. doi:10.1046/j.1365-294x.2000.00890.x

[21] Palomares, F., Godoy, J.A., Piriz, A., O’Brien, J. and Johnson, W.E. (2002) Faecal genetic analysis to determine the presence and distribution of elusive carnivores: Design and feasibility for the Iberian lynx. Molecular Ecology, 11, 2171-2182. doi:10.1046/j.1365-294X.2002.01608.x

[22] Paxinos, E., McIntosh, C., Ralls, K. and Fleischer, R. (1997) A noninvasive method for distinguishing among canid species: Amplification and enzyme restriction of DNA from dung. Molecular Ecology, 6, 483-486. doi:10.1046/j.1365-294X.1997.00206.X

[23] Taberlet, P., Camarra, J.-J., Griffin, S., Uhrès, E., Hanotte, O., Waits, L.P., Dubois-Paganon, C., Burke, T. and Bouvet, J. (1997) Noninvasive genetic tracking of the endangered Pyrenean brown bear population. Molecular Ecology, 6, 869-876. doi:10.1111/j.1365-294X.1997.tb00141.x

[24] Gerloff, U., Schlötterer, C., Rassmann, K., Rambold, I., Hohmann, G., Fruth, B. and Tautz, D. (1995) Amplification of hypervariable simple sequence repeats (microsatellites) from excremental DNA of wild living bonobos (Pan paniscus). Molecular Ecology, 4, 515-518. doi:10.1111/j.1365-294X.1995.tb00247.x

[25] Dallas, J.F., Coxon, K.E., Sykes, T., Chanin, P.R.F., Marshall, F., Carss, D.N., Bacon, P.J., Piertney, S.B. and Racey, P.A. (2003) Similar estimates of population genetic composition and sex ratio derived from carcasses and faeces of Eurasian otter Lutra lutra. Molecular Ecology, 12, 275-282. doi:10.1046/j.1365-294X.2003.01712.x

[26] Green, M.L., Herzing, D.L. and Baldwin, J.D. (2007) Noninvasive methodology for the sampling and extraction of DNA from free-ranging Atlantic spotted dolphins (Stenella frontalis). Molecular Ecology Notes, 7, 1287 1292. doi:10.1111/j.1471-8286.2007.01858.x

[27] Parsons, K.M., Dallas, J.F., Claridge, D.E., Durban, J.W., 
Balcomb III, K.C., Thompson, P.M. and Noble, L.R. (1999) Amplifying dolphin mitochondrial DNA from faecal plumes. Molecular Ecology, 8, 1766-1768. doi:10.1046/j.1365-294x.1999.00723-8.x

[28] Reed, J.Z., Tollit, D.J., Thompson, P.M. and Amos, W. (1997) Molecular scatology: The use of molecular genetic analysis to assign species, sex and individual identity to seal faeces. Molecular Ecology, 6, 225-234. doi:10.1046/j.1365-294X.1997.00175.x

[29] Tikel, D., Blair, D. and Marsh, H.D. (1996) Marine mammal faeces as a source of DNA. Molecular Ecology, 5, 456-457.

[30] Barbosa, S., Pauperio, J., Searle, J.B. and Alves, P.C. (2013) Genetic identification of Iberian rodent species using both mitochondrial and nuclear loci: Application to noninvasive sampling. Molecular Ecology Resources, 13, 43-56. doi:10.1111/1755-0998.12024

[31] Taberlet, P. and Luikart, G. (1999) Non-invasive genetic sampling and individual identification. Biological Journal of the Linnean Society, 68, 41-55.

doi:10.1111/j.1095-8312.1999.tb01157.x

[32] Helgen, K.M., Cole, F.R., Helgen, L.E. and Wilson, D.E. (2009) Generic revision in the holarctic ground squirrel genus Spermophilus. Journal of Mammalogy, 90, 270305. doi:10.1644/07-MAMM-A-309.1

[33] Lewis, T. and Rongstad, O. (1992) The distribution of Franklin's ground squirrel in Wisconsin and Illinois. Wisconsin Academy of Sciences, Arts and Letters, 80, 57-62.

[34] Ostroff, A.C. and Finck, E.J. (2003) Spermophilus franklinii. Mammalian Species, 724, 1-5. doi:10.1644/724

[35] Thorington, R.W., Koprowski, J.L., Steele, M.A. and Whatton, J.F. (2012) Squirrels of the world. Johns Hopkins University Press, Baltimore.

[36] Illinois Endangered Species Board (2011) Checklist of endangered and threatened animals and plants of Illinois. http://www.dnr.illinois.gov/ESPB/Documents/ETCheckli st2011.pdf

[37] Indiana Department of Natural Resources (2012) Indiana's State endangered species.

http://www.in.gov/dnr/fishwild/files/fw-State_Endangere d_Species_list.pdf

[38] Iowa Department of Natural Resources (2012) Iowa wildlife action plan.

http://www.iowadnr.gov/Environment/WildlifeStewardshi $\mathrm{p} /$ IowaWildlifeActionPlan.aspx

[39] Missouri Department of Conservation (2013) Missouri species and communities of conservation concern checklist.

http://mdc.mo.gov/sites/default/files/resources/2010/04/2 013 species concern.pdf

[40] Wisconsin Department of Natural Resources (2013) Franklin's ground squirrel (Spermophilus franklinii). http://dnr.wi.gov/topic/endangeredresources/animals.asp? mode $=$ detail \&speccode $=$ amafb 05120

[41] Piggott, M.P. (2004) Effect of sample age and season of collection on the reliability of microsatellite genotyping of faecal DNA. Wildlife Research, 31, 485-493. doi:10.1071/WR03096
[42] Maudet, C., Luikart, G., Dubray, D., Von Hardenberg, A. and Taberlet, P. (2004) Low genotyping error rates in wild ungulate faeces sampled in winter. Molecular Ecology Notes, 4, 772-775. doi:10.1111/j.1471-8286.2004.00787.x

[43] Sikes, R.S. and Gannon, W.L. (2011) Guidelines of the American Society of Mammalogists for the use of wild mammals in research. Journal of Mammalogy, 92, 235253. doi:10.1644/10-MAMM-F-355.1

[44] Brinkman, T.J., Person, D.K., Schwartz, M.K., Pilgrim, K.L., Colson, K.E. and Hundertmark, K.J. (2010) Individual identification of Sitka black-tailed deer (Odocoileus hemionus sitkensis) using DNA from fecal pellets. Conservation Genetics Resources, 2, 115-118. doi:10.1007/s12686-010-9176-7

[45] Goossens, B., Waits, L.P. and Taberlet, P. (1998) Plucked hair samples as a source of DNA: Reliability of dinucleotide microsatellite genotyping. Molecular Ecology, 7, 1237-1241. doi:10.1046/j.1365-294x.1998.00407.x

[46] Frantzen, M.A.J., Silk, J.B., Ferguson, J.W.H., Wayne, R.K. and Kohn, M.H. (1998) Empirical evaluation of preservation methods for faecal DNA. Molecular Ecology, 7, 1423-1428. doi:10.1046/j.1365-294x.1998.00449.x

[47] Taberlet, P., Waits, L.P. and Luikart, G. (1999) Noninvasive genetic sampling: Look before you leap. Trends in Ecology and Evolution, 14, 323-327. doi:10.1016/S0169-5347(99)01637-7

[48] Green, M.L., Herzing, D.L. and Baldwin, J.D. (2011) Reproductive success of male Atlantic spotted dolphins (Stenella frontalis) revealed by noninvasive genetic analysis of paternity. Canadian Journal of Zoology, 89, 239253. doi:10.1139/Z10-111

[49] Bonin, A., Bellemain, E., Bronken Eidesen, P., Pompanon, F., Brochmann, C. and Taberlet, P. (2004) How to track and assess genotyping errors in population genetics studies. Molecular Ecology, 13, 3261-3273. doi:10.1111/j.1365-294X.2004.02346.x

[50] Ruibal, M., Peakall, R., Claridge, A., Murray, A. and Firestone, K. (2010) Advancement to hair-sampling surveys of a medium-sized mammal: DNA-based individual identification and population estimation of a rare Australian marsupial, the spotted-tailed quoll (Dasyurus maculatus). Wildlife Research, 37, 27-38. doi:10.1071/WR09087

[51] Gagneux, P., Boesch, C. and Woodruff, D.S. (1997) Microsatellite scoring errors associated with noninvasive genotyping based on nuclear DNA amplified from shed hair. Molecular Ecology, 6, 861-868. doi:10.1111/j.1365-294X.1997.tb00140.x

[52] Mowat, G. and Strobeck, C. (2000) Estimating population size of grizzly bears using hair capture, DNA profiling, and mark-recapture analysis. The Journal of Wildlife Management, 64, 183-193. doi:10.2307/3802989

[53] Woods, J.G., Paetkau, D., Lewis, D., McLellan, B.N., Proctor, M. and Strobeck, C. (1999) Genetic tagging of free-ranging black and brown bears. Wildlife Society Bulletin, 27, 616-627.

[54] Brinkman, T.J., Schwartz, M.K., Person, D.K., Pilgrim, K.L. and Hundertmark, K.J. (2010) Effects of time and rainfall on PCR success using DNA extracted from deer 
fecal pellets. Conservation Genetics, 11, 1547-1552. doi:10.1007/s10592-009-9928-7

[55] Navidi, W., Arnheim, N. and Waterman, M.S. (1992) A multiple-tubes approach for accurate genotyping of very small DNA samples using PCR: Statistical considerations. American Journal of Human Genetics, 50, 347-359.

[56] Taberlet, P., Griffin, S., Goossens, B., Questiau, S., Manceau, V., Escaravage, N., Waits, L.P. and Bouvet, J. (1996) Reliable genotyping of samples with very low DNA quantities using PCR. Nucleic Acids Research, 24, 31893194. doi:10.1093/nar/24.16.3189

[57] Matsuda, H., Imaizumi, K., Kubota, S., Miyasaka, S., Yoshina, M. and Seta, S. (1997) Technical investigation of DNA extraction from single hair shaft. Reports of the National Research Institute of Police Science, 50, 23-28.

[58] Hellmann, A., Rohleder, U., Schmitter, H. and Wittig, M. (2001) STR typing of human telogen hairs-A new approach. International Journal of Legal Medicine, 114,
269-273. doi: $10.1007 / \mathrm{s} 004140000175$

[59] Sanecki, G.M. and Green, K. (2005) A technique for using hair tubes beneath the snowpack to detect winter-active small mammals in the subnivean space. European Journal of Wildife Research, 51, 41-47. doi:10.1007/s10344-004-0069-5

[60] Scotts, D.J. and Craig, S.A. (1988) Improved hair-sampling tube for the detection of rare mammals. Australian Wildlife Research, 15, 469-472. doi:10.1071/WR9880469

[61] Suckling, G.C. (1978) A hair sampling tube for the detection of small mammals in trees. Australian Wildlife Research, 5, 249-252. doi:10.1071/WR9780249

[62] Foran, D.R., Minta, S.C. and Heinemeyer, K.S. (1997) DNA-based analysis of hair to identify species and individuals for population research and monitoring. Wildlife Society Bulletin, 25, 840-847. 